\title{
Hubungan Stres Akademik dan Subjective Well-Being pada Anak dan Remaja Selama Pembelajaran Daring
}

\section{Hafidzal Rizkia Achmad*, Hedi Wahyudi}

Prodi Ilmu Psikologi, Fakultas Psikologi, Universitas Islam Bandung, Indonesia.

*hrizkiaachmad@gmail.com, hedi.wahyudi@unisba.ac.id

\begin{abstract}
The COVID-19 pandemic has had an impact on all fields, including education. Educational methods have also changed from being face-to-face to online learning. Many students complain about online learning methods which give too many assignments and limited working time. Students must adapt starting from the way they study, do assignments, and other situations that can have an impact on student stress. This study aimed to find out the relationship between academic stress and subjective well-being in children and adolescents during online learning and to see how closely the two are related. The method used in this study uses the correlational method to see the relationship between the two variables and uses a quantitative approach for measurement. Measurements used the Student-Life Stress Inventory (SLSI), and the Children's World Subjective Well Being Scale (CW-SWBS). The sample used by all children and adolescents in Indonesia aged 10-18 years who experienced online learning was 3081. Analysis using Rank Spearmen, the results showed that there was a negative and low relationship between academic stress and subjective wellbeing in children and adolescents aged 10-18 years with a value of - .286
\end{abstract}

Keywords: Covid-19 Pandemic, Students, Academic Stress, Subjective Well-Being.

Abstrak. Pandemi COVID-19 memberikan dampak ke segala bidang termasuk ke bidang penidikan. Metode pendidikan pun berubah yang awalnya bisa bertatap muka menjadi pembelajaran dalam jaringan (daring). Banyak pelajar yang mengeluh mengenai metode pembelajaran daring yang mana pemberian tugas yang terlalu banyak serta waktu pengerjaan yang terbatas. Para pelajar harus beradaptasi mulai dari cara belajar, mengerjakan tugas serta dengan situasi lainnya yang dapat berdampak pada stres pelajar. Penelitian ini ditujukan untuk mencari tahu keterkaitan antara stres akademik dengan subjective well-being pada anak dan remaja selama pembelajaran daring. Serta melihat seberapa erat hubungan keduanya. Metode yang digunakan dalam penelitian menggunakan metode korelasioanl untuk melihat hubungan kedua variabel serta menggunakan pendekatan kuantitatif untuk pengukuran. Pengukuran menggunakan alat ukur Student-Life Stress Inventory (SLSI), dan Children's Wolrds Subjective Well Being Scale (CW-SWBS). Sampel yang digunakan seluruh anak dan remaja di Indonesia usia 10-18 tahun yang mengalami pembelajaran daring yaitu 3081. Analisis menggunakan Rank Spearmen, hasil penelitian menunjukkan terdapat hubungan negatif dan rendah antara stres akademik dengan subjevtive well-being pada anak dan remaja usia 10-18 tahun dengan nilai sebesar -.286

Kata Kunci: Pandemi Covid-19, Pelajar, Stres Akademik, Subjective Well-Being. 


\section{A. Pendahuluan}

Pada masa pandemi ini semua sektor dirugikan salah satunya sektor Pendidikan. Keadaan ini mengakibatkan Kementerian Pendidikan dan Kebudayaan (Kemendikbud) mempersiapkan skenario pembelajaran dari rumah sampai 2020 akhir. Surat Edaran Nomor 4 Tahun 2020 tentang Pelaksanaan Kebijakan Pendidikan dalam Masa Darurat Penyebaran Corona Virus Disease (COVID-19) yang mentapkan bahwa pembelajaran dilaksanakan dengan cara jarak jauh ataupun daring. Dalam Surat Edaran Menteri Pendidikan dan Kebudayaan (Mendikbud) No 4 Tahun 2020, disebutkan bahwa selagi masa PJJ, guru dilarang mengejar ketercapaian kurikulum dikarenakan keterbatasan lingkungan, media pembelajaran, sarana, serta waktu yang bisa menjadi hambatan dalam proses belajar. Namun, pada kenyataanya malah banyak guru yang memberi tugas secara nonstop kepada siswa selagi PJJ guna tetap mengejar ketercapaian kurikulum. Dispekulasikan oleh Retno, dikarenakan keegoisan sekolah dalam mencapai kurikulum, siswa banyak yang merasa dibebani sampai tertekan secara psikologis, tidak naik kelas, bahkan hingga berhenti sekolah. Setelah penerapan peraturan tersebut sebanyak 213 pengaduan telah diterima oleh Komisi Perlindungan Anak Indonesia (KPAI) dalam rentang waktu sejak 16 Maret - 9 April 2020, dimana sebanyak $70 \%$ aduan berisi tentang keluhkesah mengenai tugas yang diberi pihak sekolah dengan batas pengerjaan yang amat pendek. Kemudian Hasil Analisa memperlihatkan sebagian tema serta hasil distribusinya dari apa saja yang mempengaruhi stres akademik yakni tugas pembelajaran $(70,29 \%)$, bosan dirumah saja $(57,8 \%)$, pelaksanaan pembelajaran daring yang mulai membosankan (55,8\%), tidak bisa berjumpa dengan orang yang disayangi $(40,2 \%)$, tidak bisa mengikuti pembelajaran daring dikarenakan keterbatasan sinyal $(37,4 \%)$, tidak bisa melakukan hobi seperti biasanya $(35,8 \%)$, tidak bisa mengaplikasikan pembelajaran praktek laboratorium dikarenakan tidak tersedianya alat (35\%). (Livana PH et al,. 2020).

Beberapa hasil menunjukkan bahwa fungsi akademis yang lebih tinggi mengarah ke SWB yang lebih tinggi dan tingkat psikopatologi yang lebih rendah (Suldo \& Shaffner, 2008) dan bahwa IPK siswa secara positif memprediksi perubahan dalam kepuasan hidup (Steinmayr et al., 2015). Subjective well-being ialah sebuah bentuk evaluasi terkait kehidupan pribadi yang bersangkutan. Evaluasi ini bisa dilaksanakan melewati 2 cara, yakni respon emosional terhadap kejadian serta penilaian secara kognitif (Diener, 2002). Manfaat bagi daya tahan tubuh serta kesehatan, dimana individu yang berbahagia tidak gampang sakit, cenderung berumur panjang, lebih sehat, serta mampu mengontrol diri merupakan salah satu manfaat positive mempunyai level subjective well-being yang tinggi (Diener \& Chan, 2011).

Individu yang bisa melakukan kontrol atas emosinya, menghadapi beragam kejadian di hidup dengan lebih baik, serta melakukan evaluasi kepuasan hidup. Sementara itu, individu yang tidak dapat melakukan evaluasi atas hidupnya lebih condong melihat rendah kehidupannya serta beranggapan bahwa kejadian yang terjadi menjadi hal yang tidak menyenangkan. Faktor tersebutlah yang mengakibatkan munculnya emosi yang tidak membuat senang, misalnya rasa marah, stres, serta rasa cemas (Myers \& Diener, 2000). Penelitian Hasanah (2020) remaja menghadapi stres semasa pandemic Covid-19. Agar bisa menjalani hidup, remaja dipaksa untuk menyesuaikan diri selama pandemi, dimana peralihan perilaku semacam aktivitas pendidikan yang wajib disesuaikan dalam era pandemi ini menyebabkan remaja sensitif terhadap stres (Hasanah et al., 2020).

Stres akademik ialah tekanan diakibatkan persepsi subjektif terkait sebuah keadaan akademik. Tekanan tersebut memunculkan respon terjadi pada siswa seperti reaksi emosi, pikiran, fisik, serta perilaku negative yang hadir disebabkan terdapatnya tuntutan akademik ataupun sekolah. Berdasarkan (Puspitasari, W. 2013; Gunawati, R., Hartati, S., \& Listiara, A. 2010), terdapat beberapa faktor yang mampu memengaruhi stres akademik, yakni faktor internal serta faktor eksternal . Faktor internal terdiri atas keyakinan, kepribadian, serta pola pikir. Sementara itu, faktor eksternal meliputi dorongan status sosial, orang tua yang saling berlomba, pelajaran lebih padat, serta tekanan untuk berprestasi tinggi. Stres pada remaja, terutama pada remaja SMA, berdasarkan yang disampaikan Baldwin ditengah menghadapi tekanan pelajaran yang dianggap lumayan berat disekolah mampu menyebabkan stres terhadap remaja, dimana umumnya remaja dalam masa ini mengalami tekanan bersumber dari bagian 
sekolah serta terkadang dari orangtua guna mendapatkan nilai tinggi guna mampu meneruskan pendidikan menuju universitas favorit (Desmita, 2009).

Hasil penelitian oleh Denovan dan Macaskill (2017) memperlihatkan tingkat stres pada mahasiswa tetap stabil walaupun waktu belalu serta didapati kenaikan alienasi atas aktivitas akademik serta self-efikasi menurun dengan pengukuran pada 3 minggu pertama perkuliahan serta 6 bulan selanjutnya, terhadap 192 mahasiswa UK ditahun pertama. Stress yang secara lanjut berasosiasi negative dengan kepuasan hidup serta berasosiasi positive atas efek negatif pada kedua pengukuran (tiga minggu serta enam bulan), namun terhadap afek positif hanya berasosiasi negatif terhadap pengukuran kedua (enam bulan) (Denovan \& Macaskill 2017). Kemudian penelitian yang dilakukan oleh Wicaksono (2018) terhadap 43 orang mahasiswa magister memperlihatkan didapati korelasi negatif antara stress akademik dengan kepuasan hidup yang manandakan apabila kepuasan individu semakin tinggi, maka tingkat stres akademik yang dirasakan oleh individu tersebut akan semakin rendah (Wicaksosno, 2018).

Namun dalam konteks seseorang memiliki tingkat kesejahteraan dapat dengan cepat menyelesaikan permasalahan, hal ini berkaitan dengan apa yang peneliti ingin teliti. Masalah dalam penelitian yang hendak di teliti, kebanyakan peneliti dengan subjek mahasiswa, disini peneliti ingin melihat situasi yang dialami oleh siswa. Oleh sebab itu, peneliti hendak melihat sejauh mana gambaran subjective well-being pada setiap siswa sehingga dapat mereduksi permasalahan-permasalahan yang dihadapi selagi proses pembelajaran. Selain itu bagaimana subjective well-being pada siswa selama pembelajaran daring, yang notabene pembelajaran daring kebanyakan hanya pemberian tugas dari para guru. Urgensi penelitian ini adalah bagaimana kondisi anak maupun remaja pada pembelajaran daring bisa mengikuti pembelajaran dengan optimal, selanjutnya agar sekolah kembali mempertimbangkan kembali kurikulum yang sesuai dengan kondisi saat pandemi. Oleh karena itu, peneliti berminat untuk melakukan penelitian Hubungan Stres Akademik Subjective Well-Being Pada Anak dan Remaja Selama Pembelajaran Daring.

Berdasarkan latar belakang yang telah diuraikan, maka perumusan masalah dalam penelitian ini sebagai berikut: Bagaimana gambaran stres akademik pada anak dan remaja selama pembelajaran daring, bagaimana gambaran subjective well-being pada anak dan remaja selama pembelajaran daring, dan Seberapa erat hubungan stres akademik dan subjective wellbeing pada anak dan remaja selama pembelajaran daring. Selanjutnya tujuan dari penelitian ini Untuk memperoleh data serta menjelaskan hubungan antara subjective well-being dan stres akademik pada anak dan remaja selama pembelajaran daring dan menentukan seberapa erat hubungan di antara keduanya.

\section{B. Metodologi Penelitian}

Peneliti menggunakan teori dari Diener untuk subjective Well-being serta teori Gadzella dan Martin untuk stres akademik. Subjective well-being merupakan kondisi dimana individu merasa puas dan bahagia atas hidupnya yang seasuai dengan diharapkan dimana dipengaruhi oleh afek positif, rendahnya afek negatif, serta kepuasan hidup. Kepuasan hidup merupakan penilaian tentang kualitas hidup, afeksi positif respon emosi yang membuat senang, dan afek negatif bentuk mood serta emosi yang tidak membuat senang sehingga merefleksikan respon negatif. Stres akademik merupakan kondisi siswa tidak mampu memenuhi tuntuan akademik yang disebabkan oleh kapabilitas siswa yang kurang mumpuni. Yang kemudian menyebabkan reaksi seperti reaksi perilaku, emosi, fisik, serta kognitif, yang muncul akibat dari rasa frustasi akibat terlambat dalam mencapai tujuan, konflik dalam memilih alternatif pilihan, tekanan terhadap beban kerja, perubahan yang tidak menyenangkan, dan keinginan diri untuk bersaing.

Penelitian ini menggunakan pendekatann kuantitatif serta metode korelasional. Pendekatan kuantitaif digunakan aspek pengukuran, perhitungan, rumus dalam proses untuk menghasilkan data. Penelitian korelasional diarahkan guna menangkap hubungan suatu variabel lainnya berdasarkan Sukmadinata (2010). Metode korelasional digunakan dalam penelitian untuk dilibatkan dalam pengumpulan data dan menentukan, apakah ada hubungan pada variabel, baik positif ataupun negatif. Convenience sampling ialah teknik sampling yang 
dimanfaatkan pada penelitian ini. Teknik sampling ini adalah teknik sampling nonprobabilitas, di mana anak dan remaja menjadi sampel karena mereka memungkinkan untuk dijadikan sampel (Etikan, 2016). Populasi dan sampel anak dan remaja dengan usia 10-18 tahun di seluruh Indonesia. Menggunakan analsisi statistika Korelasi Rank Spearman dimanfaatkan guna melacak hubungan dalam pengujian signifikansi hipotesis asosiatif apabila masingmasing variabel yang di hubungkan berbentuk Ordinal.

\section{Hasil Penelitian dan Pembahasan}

Berikut adalah penelitian mengenai hubungan stres akademik dan subjective well-being pada anak dan remaja selama pembelajaran daring, yang diuji menggunakan teknik analisis korelasi Rank Spearman. Hasil pengujian sebagai berikut

Tabel 1. Karakteristik Sampel

\begin{tabular}{llll}
\hline No. & Tingkat Pendidikan & Frekuensi & Persentase \\
\hline 1. & SD (Kelas 4-6) & 304 & $9.9 \%$ \\
\hline 2. & SMP & 978 & $30.8 \%$ \\
\hline 3. & SMA & 1.642 & $53.2 \%$ \\
\hline 4. & Kuliah & 187 & $6.1 \%$
\end{tabular}

Dari tabel tersebut diketahui karakteristik sampel berdasarkan tingkat pendidikan, bahwa 304 responden berasal dari SD kelas 4-6 dengan persentase 9.9\%, selanjutnya 978 responden berasal dari SMP dengan persentase 30.8\%, 1.642 responden berasal dari SMA dengan persentase $53.2 \%$, dan 187 responden berasal dari Kuliah dengan persentase $6.1 \%$.

Tabel 2. Kategori Stres Akademik dan Subjective Well-Being

\begin{tabular}{|c|c|c|}
\hline $\begin{array}{c}\text { Tingkat } \\
\text { Pendidikan }\end{array}$ & $\begin{array}{c}\text { Subjective } \\
\text { Well- } \\
\text { Being }\end{array}$ & $\begin{array}{c}\text { Stres } \\
\text { Akademik }\end{array}$ \\
\hline $\begin{array}{l}\text { SD (Kelas } \\
4-6)\end{array}$ & $\begin{array}{c}\text { Mean= } \\
85,67 \\
\mathrm{SD}=21\end{array}$ & $\begin{array}{c}\text { Mean= } \\
72,67 \\
\text { SD 19.34 }\end{array}$ \\
\hline \multirow[t]{2}{*}{ SMP } & $\begin{array}{c}\text { Mean }= \\
84,6\end{array}$ & $\begin{array}{c}\text { Mean }=72, \\
34\end{array}$ \\
\hline & $\mathrm{SD}=26,6$ & $\mathrm{SD}=24$ \\
\hline \multirow[t]{2}{*}{ SMA } & Mean 100 & Mean $=68$ \\
\hline & $\mathrm{SD}=21,6$ & $\begin{array}{c}\mathrm{SD}=23 \\
34\end{array}$ \\
\hline \multirow[t]{2}{*}{ Kuliah } & Mean $=99$ & Mean $=67$ \\
\hline & $\mathrm{SD}=22$ & $\mathrm{SD}=23$ \\
\hline
\end{tabular}

Berdasarkan tabel di atas menggambarkan hasil perhitungan mengenai besaran nilai stres akademik maupun subjectve well-being. Sebagai penggambaran subjective well-being menghasilkan bahwa semua tingkatan pendidikan mempunyai subjective well-being yang tinggi, hal ini terlihat dimana makin tinggi pendidikan individu, akan makin tinggi pula jika 
dipandang dari segi faktor demografsinya. Dijelaskan oleh Diener (2005), sejauh apa faktor demografis, tertentu mampu dilakukan peningkatan subjective well-being bergantung dengan tujuan serta nilai yang dipunyai seorang individu, kultur, serta kepribadian.

Kemudian melihat dari tabel 4.9 hubungan antara tingkat pendidikan dengan stres akademik dapat dilihat bahwa tingkat stres yang paling tinggi berada pada atingkat SD (kelas 4-6). Seperti yang terlihat pada fakta di lapangan bahwa semakin tinggi tingkat pendidikan maka beban yang diemban sesorang tersebut tekanan, dan lain sebagainya akan semkain berat. Mengingat pelajaran SD belum terlalu padat, namun dilihat dari segi lainnya faktor eksternal seperti orang tua yang saling berlomba, tekanan untuk berprestasi dan dorongan status sosial menjadi sesuatu hal yang harus digaris bawahi.

Tabel 3. Uji Hipotesis

\begin{tabular}{lcl}
\hline \multicolumn{1}{c}{ Hubungan } & \multicolumn{1}{c}{ Hasil Pengujian } & \multicolumn{1}{c}{ Keterangan } \\
\hline Hubungan Subjective & $\mathrm{rs}=-0,286$ & Terdapat hubungan \\
Well-Being dengan Stres & $\mathrm{p}$ value $=0,000<\alpha=0,05$ & negatif antara Subjective \\
Akademik & & Well-Being dan Stres \\
& & Akademik, keratin \\
& hubungan lemah karena \\
& kurang dari 9,5 dan \\
& signifikan
\end{tabular}

Berdasarkan perhitungan statistik di atas, menghasilkan koefisien korelasi Rank Spearman antara Subjective Well-Being dengan Stres Akademik yaitu sebesar -0.286 dengan nulai $\mathrm{p}$ sebesar 0.000 lebih kecil dari nilai $\alpha$ yaitu 0,05 . Artinya terdapat hubungan antara Subjective Well-Being dan Stres Akademik denganarah hubungan yang negative namun signifikan dengan tingkat keeratan hubungan lemah. Subjective well-being berperan apabila mood pelajar positif akan mengjasilan perhatian yang lebih luas dan pikiran yang lebuh jernih dan kereatif, selanjutnya akan menunjang peningkatan dalam pembelajaran dan semakin sejahtera akan bersinergi dengan belajar yang baik. Dan menurut Diener dan Chan (2011) manfaat mempunyai subjective well -being tinggi memiliki keuntungan pada daya tahan tubuh serta kesehatan (Diener \& Chan, 2011). Siswa akan dapat mengatur stres dengan cara konstruktif berdasarkan hal tersebut.

Kemudian, untuk derajat korelasi antara kedua variabel berada pada level lemah. Berbanding tebalik oleh peneliti terdahulu yang menyatakan secara signifikan adanya hubungan antar subjective well-be ing dengan stres akademik (M. Yovita \& S.R. Asih, 2018). Hal disebabkan adanya perbedaan beberapa stressor selain stres akademik, pada penelitian lain dimana kondisi tidak sedang pandemi. Pandemi melahirkan beberapa stressor-stressor baru yang membuat masing-masing individu mengalami adaptasi terhadap kebiasaan baru. Dan memungkin faktor eksternal lainnya yang membuat stres akademik diantaranya self efficacy, Hardiness, motivasi berprestasi, prokrasitnasi serta dukungan sosial. Hal tersebut dapat menyatakan kenapa keeratan hubungan antar subjective well-be ing dengan stres akademik tidak signifikan dengan penelitian terdahulu.

\section{Kesimpulan}

Berlandas pada hasil analisis serta pembahasan di atas bisa dipetik kesimpulan yaitu sebagai berikut,

Terdapat hubungan negative dan rendah dengan nilai sebesar -,286 antara stres akademik dengan subjective well-bieng. Untuk nilai peraspek yaitu, tidak adanya hubungan antara aspek stres akademik dengan subjective well-being dengan nilai sebesar -.053. Selanjutnya pada aspek reaksi stres akademik memiliki hubungan yang negatif dan rendah dengan subjective well-being dengan nilai sebesar -.291. Dapat disimpulkan apabila semakin tinggi stres akademik seseorang maka semakin rendah subjective well-being. 
Selanjutnya gambaran subjective well-being menunjukkan dimana semua kategori nya berada di level tinggi.

Kemudian untuk gambaran stres akademik menyatakakan bahwa semua itu baik SD sampai dengan Kuliah berada ditingkat Rendah.

\section{Acknowledge}

Dalam penerbitan artikel ilmiah ini peneliti ingin menyampaikan rasa terimakasih atas sebesar-besarnya kepada.

1. Kepada Dr. Hedi Wahyudi, M.Psi Psikolog dan Dr. Ihsana Sabriani Borualogo, M.Si Psikolog selaku pembimbing penelitian yang telah membeerikan pengarahan penliti dala proses penelitian.

2. Kepada para dosen yang memberikan ilmu pembelajaran sehingga peneliti dapat memahami penelitian.

3. Kepada kedua orang tua peneliti, Ahmad Syahroni dan Rohati yang telah membesarkan, mendidik, mengajarkan arti kehidupan dan membiayai pendidikan peneliti hingga saat ini.

4. Kepada sahabat peneliti, Nadia Ayu, Aulia Bilqisfa, Maureen Ratna, serta Kirana Salama.

5. Kepada Rosalina Oktaviani, Azzahra Safira, Rik Baehaki, dan M. Faqih yang mendengarkan keluh kesah serta teman berbagi dalam menyelesaikan masalah.

6. Kepada teman kelas B 2017

7. Serta para responden yang terlibat yang namanya tidak dapat peneliti sebtutkan.

Semoga Individu-individu terkait dapat senantiasa hidup dengan kebahagiaan, kesehatam, serta perlindungan YME.

\section{Daftar Pustaka}

[1] Antara. (2020). KPAI: Banyak Siswa Stres Hingga Putus Sekolah karena Belajar Daring. medcom.id. https://www.medcom.id/pendidikan/news pendidikan/Rb10xmXNkpai-banyak-siswa-stres-hingga-putus-sekolah-karena-belajar-daring (diakses pada tanggal 12 Desember 2020).

[2] Barseli, M., Ifdil, I., \& Nikmarijal, N. (2017). Konsep stres akademik siswa. Jurnal konseling dan pendidikan, 5(3), 143-148. https://doi.org/10.29210/119800

[3] Borualogo, I. S., \& Casas, F. (2019). Adaptation and Validation of The Children's Worlds Subjective Well-Being Scale (CW-SWBS) in Indonesia. Jurnal Psikologi, 46(2), 102. https://doi.org/10.22146/jpsi.38995

[4] Borualogo, I. S., \& Casas, F. (2021a). Subjective well-being of bullied children in Indonesia. Applied Research in Quality of Life, 16, 753-773. https://doi.org/10.1007/s11482-019-09778-1

[5] Choi, C., Lee, J., Yoo, M. S., \& Ko, E. (2019). South Korean children's academic achievement and subjective well-being: The mediation of academic stress and the moderation of perceived fairness of parents and teachers. Children and Youth Service Review, 100, 22-30. 10.1016/j.childyouth.2019.02.004

[6] Desmita. (2009). Perkembangan Peserta didik. Bandung: PT Remaja Rosdakarya.

[7] Diener, E. (1984). Subjective well-being. Psychological Bulletin, 95(3), 542-575 https://psycnet.apa. org/doi/10.1037/0033-2909.95.3.542.

[8] Diener, E. (2006) Guidelines For National Indicators Of Subjective Well Being And Well Being, Applied Research In Quality Of Life, I (2),

[9] Diener, E., \& Biswas-Diener, R. (2003). Findings on Subjective Well-Being and Their Implications for Empowerment.

[10] Diener, E., Oishi, S., \& Lucas, R. E. (2015). National Accounts of subjective wellbeing. American Psychological Association, 70(3), 234-242 https://psycnet.apa.org/doi/10.1037/a0038899.

[11] Diener, E., Suh, M. \& Oishi, S. (1997). Recent findings on subjective well-being. Indian 
Journal of Clinical Psychology. 24(1), 25-41.

[12] Edaran, S., \& MELAKSANAKAN, S. Y. (2020). Kementerian Pendidikan dan Kebudayaan.

[13] Gadzella \& Masten. (2005). An analysiis off the category in students life stres inventories. American Journal of Psychollogical Research, vol. 1, no. 1, hh.1-10.

[14] Hasanah, U., Fitri, N. L., Supardi, S., \& Livana, P. H. (2020). Depresion Among Colege Student Due the COVID-19 Pandemic. Jurnal Keperawatan Jiwa, 8(4), 421-424. https://jurnal.unimus.ac.id/index.php/JKJ/article/view/6095/pdf

[15] Livana, P. H., Mubin, M. F., \& Basthomi, Y. (2020). " Learning Task" Attributable to Students' Stress During the Pandemic Covid-19. Jurnal Ilmu Keperawatan Jiwa, 3(2), 203-208. DOI: http://dx.doi.org/10.32584/jikj.v3i2.590

[16] McKnight, C. G., Huebner, E. S., \& Suldo, S. (2002). Relationships among stressful life events, temperament, problem behavior, and global life satisfaction in adolescents. Psychology in the Schools, 39(6), 677-687

[17] Wardhani, G. Y., \& Imawati, D. (2020). PERBEDAAN TINGKAT STRES AKADEMIK PADA SISWA SEKOLAH MENENGAH ATAS UMUM (SMAN 1) DENGAN SISWA SEKOLAH MENENGAH ATAS BERBASIS AGAMA (MAN 1) DI SENDAWAR. MOTIVASI, 7(1), 103-110. http://ejurnal.untagsmd.ac.id/index.php/MTV/article/view/4511/4371

[18] Wicaksono, L. (2018). HUBUNGAN SUBJECTIVE WELL-BEINGDENGAN STRES AKADEMIK PADA MAHASISWA MAGISTER. CALYPTRA, 7(2), 1488-1498. https://journal.ubaya.ac.id/index.php/jimus/article/view/3376/2513. 